\title{
Effect of dietary supplementation with arginine and glutamine on the performance of rabbit does and their litters during the first three lactations
}

\author{
R. Delgado, R. Abad-Guamán, E. De la Mata, D. Menoyo, N. Nicodemus, J. García, \\ R. Carabaño
}

\begin{abstract}
A B S T R A C T
The aim of this work was to study whether the dietary supplementation with arginine (Arg) and glutamine (Gln) or the combination of both influence the digestibility, body composition, and reproductive performance of rabbit does during the first three parturitions. A Control diet containing $29.8 \mathrm{~g}$ nitrogen $(\mathrm{N}), 313 \mathrm{~g}$ aNDFom per $\mathrm{kg} \mathrm{DM}$ and $1.85 \mathrm{~g}$ digestible $\mathrm{N} / \mathrm{MJ}$ digestible energy (DN/DE) was formulated, and another 3 diets were obtained by adding (g/kg) $4 \mathrm{Arg}, 4$ Gln and a mixture of $4 \mathrm{Arg}$ and 4 of Gln to the Control diet. Eighty nulliparous rabbit does were randomly assigned to the diets (20/diet) before the first insemination. After each parturition litter size were homogenized within each treatment and does inseminated $11 \mathrm{~d}$ later. Chemical composition and energy content of rabbit does and their performance, litter growth and milk production were measured between birth and weaning ( $25 \mathrm{~d}$ ) along three parturitions. Amino acid supplementation increased the DN content $(P=0.015)$ and tended to increase the DN/DE ratio compared to Control group $(P=0.077)$ leading to an increase of digestible $\mathrm{N}$ intake during lactation $(P=0.004)$. In this period, Gln group had a higher DE intake compared to Control and Arg + Gln groups $(P=0.038)$. Total number kits bom per litter tended to increase in rabbit does supplemented with Arg and Gln, compared to Control and Arg + Gln groups ( $P=0.095$ ), but no effect of treatments on the number of weaned rabbits was observed $(P=0.15)$. Single supplementation of Arg and Gln increased the weight of the litters at 20 and $25 \mathrm{~d}$ respect to Control and $\mathrm{Arg}+\mathrm{Gln}$ groups $(P \leq 0.021)$. Amino acid supplementation did not affect the milk production $(P=0.16)$, although it was positively correlated with the DE and DN intake $(P<0.001)$. There were no significant effects of treatments on body weight, chemical composition and energy content of rabbit does, but does supplemented with Arg or Gln tended to have a higher body energy content at the third insemination and at weaning than those from Control and Arg + Gln groups ( $P \leq 0.099$ ). Amino acid supplementation did not modify the replacement rate of rabbit does. In conclusion, the single supplementation of Arg and Gln had a positive effect on the weight of litters at weaning and litter size at birth, but no additive effect was observed for the combined supplementation of Arg and Gln.
\end{abstract}

Abbreviations: AI, artificial insemination; Arg. arginine: BW, body weight, DE. digestible energy: DN, digestible nitrogen; Gln, glutamine: N. nitrogen; P, parturition: W, weaning 


\section{Introduction}

Litter size has a great economic importance in rabbit farms (Cartuche et al., 2014). It is affected mainly by ovulation rate and prenatal survival rate, being the latter around 0.35 both in rabbit does and in sows (Blasco et al., 1993). In rabbits, when the number of fetuses increases the vascular supply to each implantation site is reduced (Duncan, 1969). This limited blood supply may produce smaller fetuses and a higher fetal mortality rate, reducing litter weight and size at birth (Argente et al., 2003).

Arginine (Arg) and glutamine (Gln) play an important role in placental, embryonic and fetal growth during pregnancy. Arginine is used as a precursor for the synthesis of nitric oxide (NO), polyamines and other compounds (Wu and Morris, 1998). Nitric oxide plays an important role in vasodilatation and regulates the uterine blood flow promoting the transference of nutrients to the fetus (Moncada and Higgs, 1995; Bird et al., 2003). In sows during early gestation the concentration of Arg in the uterine fluids increased compared to maternal uterine plasma levels (Wu et al., 1998). This rise coincides with the time where the development of the placenta is faster (Wu et al., 2005) and suggests that both nitric oxide and polyamines are key regulators of angiogenesis and embryogenesis as well as placental and fetal growth (Wu et al., 2004). Arginine supplementation during early gestation (around $8 \mathrm{~g} /$ $\mathrm{kg}$ and 14-28 d pregnancy) in gilts improved fetal survival (Berard and Bee, 2010) whereas its supplementation (10 g/ kg) from day 30 of pregnancy to parturition increased the number of piglets born alive and their live weight (Mateo et al., 2007).

Free Gln is abundant in plasma, milk and fetal fluids (Wu, 2009), although the Gln uptake by porcine mammary glands in not adequate for milk protein synthesis (Li et al., 2009). Furthermore, the uterine uptake of Gln in pregnant gilts is the highest compared to other amino acids (Wu et al., 1999). The supplementation of lactating sows diet with $10 \mathrm{~g}$ Gln/ $\mathrm{kg}$ increased its concentration in milk and enhanced piglet growth and survival (Wu et al., 2011). However, the requirements of Arg and Gln have not been studied in rabbit does although the prolificacy increase and nutrient supply may be limited during the pregnancy and lactation.

The aim of this work was to study the effect of supplementation with Arg and Gln and their potential additive effect on the digestibility, productivity and body composition of rabbit does during the first three parturitions.

\section{Materials and methods}

\subsection{Experimental diets}

Four diets in a $2 \times 2$ factorial arrangement were used (two levels of arginine combined with two levels of glutamine). A Control diet was formulated to contain $29.8 \mathrm{~g}$ nitrogen $(\mathrm{N}) / \mathrm{kg} \mathrm{DM}$ and $313 \mathrm{~g} \mathrm{NDF} / \mathrm{kg} \mathrm{DM}$, with a minimal digestible nitrogen to digestible energy (DE) ratio ( $\mathrm{g} / \mathrm{MJ}$ ) of 1.84 (Xiccato and Trocino, 2010) and meeting the minimal nutrient requirements (De Blas and Mateos, 2010). Arginine:lysine ratio (in total basis) was fixed in $120 \%$ according to previous recommendations (INRA, 1984), that is higher than the recommended for sows (53\% on average; NRC, 2012) and the ratio Gln:lysine was fixed in 331\%, close to the Control diet used by Baylos et al. (2008). Other three diets were obtained by adding to the Control diet $4 \mathrm{~g}$ arginine/ $\mathrm{kg}$ (Arg), $4 \mathrm{~g} \mathrm{glutamine} / \mathrm{kg}$ (Gln) and a mixture of $4 \mathrm{~g}$ arginine and $4 \mathrm{~g}$ glutamine/ $\mathrm{kg}$ (Arg $+\mathrm{Gln}$ ). These treatments resulted in an increase of the Arg:lysine and Gln:lysine ratios in a 15 and $37 \%$. These doses were fixed according the positive effect observed of the supplementation with $5 \mathrm{~g}$ Gln/ $\mathrm{kg}$ on rabbit intestinal health (increase of the Gln:lysine ratio by $17 \%$; Baylos et al., 2008). The ingredient composition of Control diet

Table 1

Ingredient composition of the control diet ( $\mathrm{g} / \mathrm{kg}$ DM).

\begin{tabular}{|c|c|}
\hline Alfalfa hay & 290 \\
\hline Wheat & 220 \\
\hline Wheat bran & 220 \\
\hline Sunflower meal $28-30$ & 130 \\
\hline Soybean meal 44 & 65.0 \\
\hline Soy protein concentrate 61 & 15.0 \\
\hline Defatted grape seed meal & 20.0 \\
\hline Lard & 20.0 \\
\hline L-Lysine $\mathrm{HCl}$ & 2.00 \\
\hline DL-Methionine & 0.50 \\
\hline L-Threonine & 0.50 \\
\hline Calcium carbonate & 6.80 \\
\hline Sodium chloride & 5.00 \\
\hline Vitamin/mineral premix ${ }^{1}$ & 5.00 \\
\hline Coccidiostat ${ }^{2}$ & 0.20 \\
\hline
\end{tabular}

${ }^{1}$ Provided by Trouw Nutrition-Tecna (Madrid, España). Mineral and vitamin composition (per $\mathrm{kg}$ of complete diet): $20 \mathrm{mg}$ of $\mathrm{Mn}$ as $\mathrm{MnO} ; 59.2 \mathrm{mg}$ of $\mathrm{Zn}$ as $\mathrm{Zn}$; $10 \mathrm{mg}$ of $\mathrm{Cu}$ as $\mathrm{CuSO}_{4} \cdot 5 \mathrm{H}_{2} \mathrm{O} ; 1.25 \mathrm{mg}$ of $\mathrm{I}$ as $\mathrm{KI} ; 0.495 \mathrm{mg}$ of $\mathrm{Co}$ as $2 \mathrm{CoCO}_{3}(\mathrm{OH})_{2} \cdot \mathrm{H}_{2} \mathrm{O} ; 76 \mathrm{mg}$ of $\mathrm{Fe}$ as $\mathrm{FeCO}_{3} ; 8375 \mathrm{UI}$ of vitamin $\mathrm{A}$; 750 UI of vitamin $D_{3}, 20$ UI of vitamin E as DL- $\alpha$-tocopherol acetate, $1.0 \mathrm{mg}$ of vitamin $\mathrm{K} ; 1.0 \mathrm{mg}$ of vitamin $B_{1} ; 2 \mathrm{mg}$ of vitamin $B_{2} ; 1 \mathrm{mg}$ of vitamin $B_{6} ; 20 \mathrm{mg}$ of niacin; $54.1 \mathrm{mg}$ of betaine; $137.5 \mathrm{mg}$ of choline chloride.

${ }^{2} 1 \mathrm{ppm}$ diclazuril provided by Esteve (España). 
Table 2

Chemical composition of experimental diets $(\mathrm{g} / \mathrm{kg} \mathrm{DM})$.

\begin{tabular}{|c|c|c|c|c|}
\hline Diets & C & Arg & Gln & $\mathrm{Arg}+\mathrm{Gln}$ \\
\hline Arginine $(\mathrm{g} / \mathrm{kg})$ & 0 & 4 & 0 & 4 \\
\hline Glutamine $(\mathrm{g} / \mathrm{kg})$ & 0 & 0 & 4 & 4 \\
\hline \multicolumn{5}{|c|}{ Analyzed composition ( $\mathrm{g} / \mathrm{kg}$ DM) } \\
\hline Dry matter & 899 & 893 & 897 & 901 \\
\hline Ash & 67.5 & 71.2 & 68.9 & 71.0 \\
\hline Nitrogen & 29.8 & 30.6 & 30.1 & 30.4 \\
\hline Ether extract & 50.0 & 50.0 & 47.0 & 45.0 \\
\hline Total dietary fiber & 418 & 423 & 426 & 425 \\
\hline Neutral detergent fiber & 313 & 322 & 319 & 321 \\
\hline Acid detergent fiber & 179 & 174 & 176 & 179 \\
\hline Acid detergent lignin & 48.1 & 44.6 & 45.6 & 44.1 \\
\hline Soluble fiber & 105 & 101 & 107 & 105 \\
\hline Gross energy (MJ/kg DM) & 18.0 & 18.5 & 18.4 & 18.4 \\
\hline \multicolumn{5}{|l|}{ Amino acids $(\mathrm{g} / \mathrm{kg} \mathrm{DM})$} \\
\hline Alanine & 8.00 & 7.90 & 8.00 & 8.00 \\
\hline Arginine & 11.3 & 15,3 & 11.6 & 15.3 \\
\hline Aspartic acid & 16.1 & 16.0 & 15.9 & 16.1 \\
\hline Cystine & 2.90 & 2.90 & 2.90 & 2.90 \\
\hline Glutamic acid & 30.8 & 30.3 & 34.5 & 35.3 \\
\hline Glycine & 8.70 & 8.60 & 8.70 & 8.70 \\
\hline Histidine & 4.00 & 3.90 & 4.00 & 3.90 \\
\hline Isoleucine & 6.90 & 6.70 & 6.80 & 6.60 \\
\hline Leucine & 11.9 & 11.8 & 11.8 & 11.9 \\
\hline Lysine & 9.30 & 9.20 & 9.20 & 9.20 \\
\hline Methionine & 3.30 & 3.20 & 3.20 & 3.20 \\
\hline Phenylalanine & 8.10 & 8.00 & 8.10 & 8.00 \\
\hline Proline & 10.4 & 10.3 & 10.3 & 10.4 \\
\hline Serine & 7.90 & 7.80 & 7.70 & 8.10 \\
\hline Threonine & 7.00 & 6.90 & 6.80 & 7.00 \\
\hline Valine & 8.50 & 8.30 & 8.40 & 8,20 \\
\hline
\end{tabular}

is shown in Table 1, and chemical composition of experimental diets in Table 2.

\subsection{Lactation trial}

Eighty nulliparous rabbit does New Zealand White $\times$ Californian (line V from UPV) were assigned randomly to the four treatments ( 20 per diet) at $123 \mathrm{~d}$ of age, 6 days before the first artificial insemination (AI), with a body weight (BW) of $3.6 \pm 0.1 \mathrm{~kg}$ and with a body composition $(\mathrm{g} / \mathrm{kg}$ BW): $619 \pm 16.6$ moisture, $182 \pm 2.6$ protein, $130 \pm 17.3$ fat, $32.2 \pm 0.7$ ash and $10.4 \pm 0.7 \mathrm{MJ}$ gross energy $/ \mathrm{kg}$ BW (mean \pm standard deviation). After birth, does were inseminated $11 \mathrm{~d}$ after parturition corresponding to a theoretical kindling-to-kindling interval of $42 \mathrm{~d}$ and the weaning was at $25 \mathrm{~d}$ of lactation. Adoptions were made after parturition among rabbit does belonging to the same diets resulting an average litter size of $10.2 \pm 2.8$ kits. In order to synchronize oestrus, $48 \mathrm{~h}$ before insemination, the does were injected $25 \mathrm{IU}$ of equine chorionic gonadotropin (Segiran, Lab. Ovejero, León) (Rebollar et al., 2006). The day of insemination, does received an intramuscular injection of $1 \mu \mathrm{g}$ of buserelin Suprefact ${ }^{\circ}$ (Hoechst Marison Roussel, S.A., Madrid). Buserelin is a Gonadotropin-releasing hormone agonist (GnRH agonist) used to induce ovulation in rabbit does (Quintela et al., 2004). The semen came from rabbit males of the R line (UPV).

The experimental period began the day of the first insemination of nulliparous rabbit does and finished the day of the parturition that corresponded to the fifth insemination. Live weight, feed intake, reproductive traits and body composition were recorded (at insemination, just after parturition and at weaning) for the first five consecutive cycles (derived from the first scheduled five inseminations) in order to obtain data from the first three lactation periods. Only rabbit does that completed at least two lactations were considered in the analysis ( 56 does with three lactations and two does with two lactations). Fourteen rabbit does completed four or five consecutive parturitions, but only were considered for statistical purposes the first three parturitions. The whole information about body condition of these 14 rabbit does is shown in Fig. 1B. The bioelectrical impedance analysis technique was used to determine the chemical body composition and energy content of the does (Nicodemus et al., 2009; Pereda, 2010). Measurements of resistance and reactance were taken in rabbit does with a body composition analyzer (Model Quantum II, RJL Systems, Detroit, MI, USA) few hours after parturition, at insemination and at weaning (always after suckling), according to Romero et al. (2011). Multiple regression equations according to Nicodemus et al. (2009) were used to estimate water, protein, ash, fat and energy proportions with respect to the body weight of rabbit does. Fertility was expressed as $100 /$ number of scheduled AI (every 42 days) performed until fertile kindling. Prolificacy (total number of rabbits born alive and dead) were also measured. Mortality of young rabbits was recorded daily during lactation and was calculated as the percentage of rabbits dead with respect to the number of rabbits born alive, using the litter as experimental unit. Mortality of rabbit does was also recorded throughout the first three reproductive cycles. Does were separated from their litters after parturition. Milk production was estimated daily from weight loss of does during suckling 

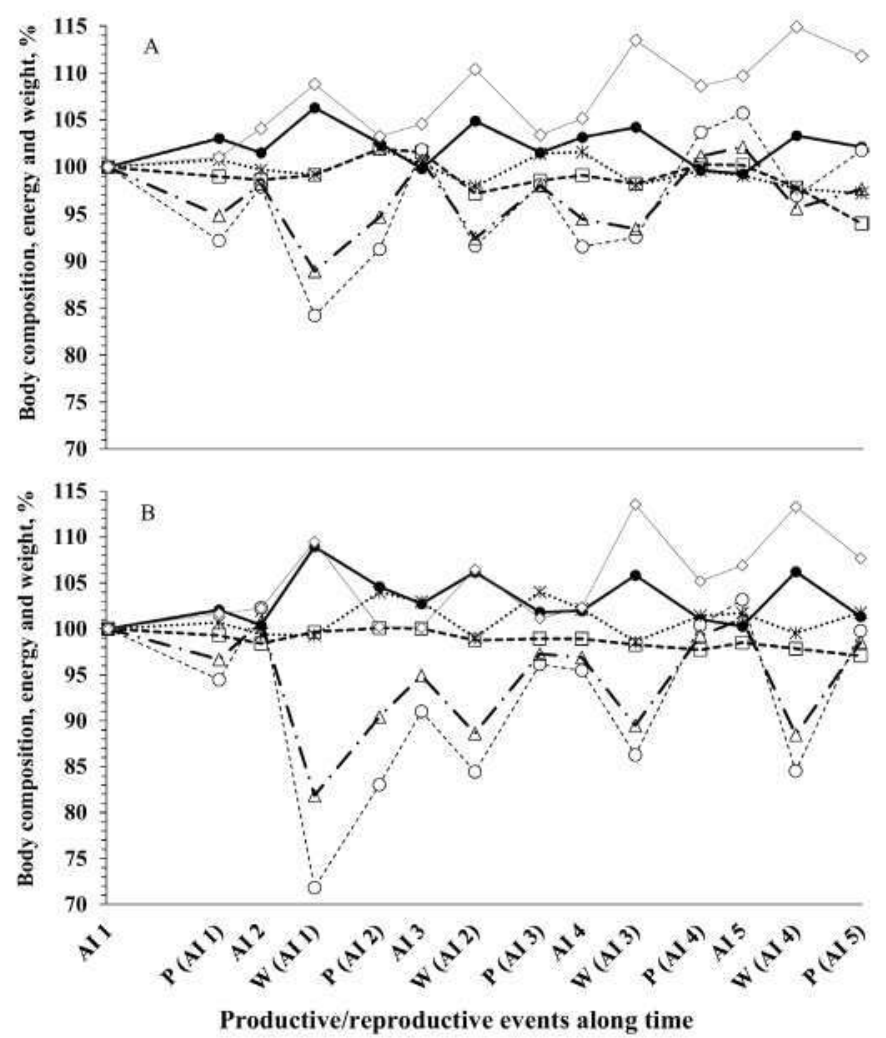

Fig. 1. Evolution of body composition, energy and weight (moisture - protein $\square$, fat $O$, ash *, energy $\Delta$, and body weight 0 ) over time (artificial insemination-AI, parturition-P and weaning -W) of all rabbit does considered for productive traits $(n=58$. (A)) or only those that had five consecutive parturitions ( $n=14$. (B)). Values obtained at first artificial insemination (AI 1) were considered as $100($ A) $-\mathrm{g} / \mathrm{kg}$ BW: moisture: $594 \pm 27$, protein: $181 \pm 3$, fat: $155 \pm 29$; ash: $31 \pm 1 \%$; energy: $11.5 \pm 1.2 \mathrm{MJ} / \mathrm{kg}$ BW; body weight: $3.9 \pm 0.2 \mathrm{~kg}$. (B) $614 \pm 32$, protein: $182 \pm 1$, fat: $135 \pm 32$; ash: $32 \pm 0.9$; energy: $10.6 \pm 1.38 \mathrm{MJ} / \mathrm{kg} \mathrm{BW}$; body weight: $3.8 \pm 0.1 \mathrm{~kg}$ ) and the values obtained later were expressed as percentage of the value obtained at $\mathrm{AI} 1$. $P_{\text {Time }}<0.001$ in both figures. AI $1, \mathrm{AI} 2$, AI 3 and $\mathrm{AI}$ 4: 1st, 2nd, 3rd and 4th artificial insemination, respectively. P (IA 1), P (IA 2), P (IA 3), P (IA 4) and P (IA 5): parturition corresponding to IA 1, AI 2, AI 3 and AI 4, respectively. W (IA 1), W (IA 2), W (IA 3) and W (IA 4): weaning corresponding to $\mathrm{IA} 1, \mathrm{AI} 2, \mathrm{AI} 3$ and AI 4, respectively.

(10 min, once a day). Litters were moved to another cage at $20 \mathrm{~d}$ of age. They were offered ad libitum the same diet than their mothers and water, and suckled once a day for $10 \mathrm{~min}$ until weaning age ( $25 \mathrm{~d}$ ). During the first gestation until $14 \mathrm{~d}$ before parturition, rabbit does were restricted to approximately $150 \mathrm{~g} / \mathrm{d}$ but afterwards they were fed ad libitum along the experiment. Only does that failed to get pregnant were also restricted between weaning and the next insemination.

\subsection{Digestibility trial}

A total of 24 rabbit does ( 6 per diet) weighing $4.06 \pm 0.30 \mathrm{~kg}$ with an average litter size of $10.4 \pm 1.4$ kits were used to determine the apparent digestibility of dry matter, gross energy, nitrogen and aNDFom. Total faecal output was collected for each doe during four consecutive days (from day 15 to 19 of the third lactation). Feed intake (ad libitum access) was recorded during this period. Feces were stored at $-20^{\circ} \mathrm{C}$ and later dried at $80^{\circ} \mathrm{C}$ for $48 \mathrm{~h}$ and ground with a $1 \mathrm{~mm}$ screen.

\subsection{Housing}

Rabbit does were housed individually in flat-deck cages $(600 \times 500 \times 320 \mathrm{~mm})$ throughout the trial and kept under controlled environmental conditions with $18-23^{\circ} \mathrm{C}$ and $16 \mathrm{~h}$ daily lighting. An external nestbox (355 $\times 230 \times 360 \mathrm{~mm}$ high) with wood shavings was provided three days before parturition. All the experimental procedures used were approved by the Animal Ethics Committee of the Universidad Politécnica de Madrid, and were in compliance with the Spanish guidelines for care and use of animals in research (BOE, 2005).

\subsection{Chemical analysis}

Procedures of the AOAC (2000) were used to determine the dietary concentrations of DM (934.01), ash (942.05), nitrogen (954.01), ether extract (920.39), and total dietary fiber (985.29). Dietary aNDFom, ADFom and lignin (sa) were determined sequentially using the filter bag system (Ankom Technology, New York, NY). Dietary aNDFom was determined according to Mertens 
et al. (2002) using a thermo-stable amylase without any sodium sulphite added. Dietary ADFom and ADL were analyzed according to AOAC (2000 and Van Soest et al. (1991), respectively. The soluble fiber was calculated as the difference between total dietary fiber and aNDFom (both corrected for ash and protein). Gross energy was measured by adiabatic bomb calorimeter (model 356, Parr Instrument Company, Moline, IL). Amino acids were determined after acid hydrolysis using a Beckman System 6300HPA AA analyzer (Fullerton, CA). Samples were hydrolyzed in $25 \mathrm{~mL}$ of $6 \mathrm{M} \mathrm{HCl}$ with $10 \mathrm{~g} / \mathrm{L}$ of added phenol for $24 \mathrm{~h}$ at $120^{\circ} \mathrm{C}$. For the determination of methionine and cystine, samples were oxidized with performic acid at $0{ }^{\circ} \mathrm{C}$ for $16 \mathrm{~h}$ and then neutralized with $0.5 \mathrm{~g}$ of sodium meta-bisulphite before analysis. During acid hydrolysis, tryptophan was destroyed and was not determined.

\subsection{Statistical analysis}

Data of faecal digestibility was analyzed as a completely randomized design with level of arginine, glutamine and their interaction as the main sources of variation by using the mixed procedure of SAS (SAS Inst., Cary, NC). Data from total removed, dead and culled does were analysed using a logistic regression (GENMOD procedure of SAS considering a binomial distribution) including the same variables in the model, and the results were transformed from the logit scale. A mixed model for repeated measures analysis was used to analyze the results obtained for the lactation and body composition traits by using the mixed procedure of SAS. The model included the level of arginine, glutamine, parity order, their interactions as fixed effects and the rabbit doe as a random effect (Littell et al., 1996). Parity order indicated for each doe the number of parturitions (at least two) along the experimental period. The number of kits in each period was used as a covariate in the model used for milk production. The evolution of body weight and composition of rabbit does was also analysed considering in the model the time of the events occurred since the beginning of the experiment (e.g. 1st, 2nd, 3rd, 4th and 5th AI) instead of the parturition order. Initial live weight, body composition (protein, fat, moisture, ash) and energy content at $123 \mathrm{~d}$ of age were used as covariates in the model used for body composition and energy content along time of rabbit does. A compound symmetry structure was fitted as it showed the lowest value of the Schwarz Bayesian criterion (Littell et al., 1998). It assumes that measures over time on the same animals had the same variance and that all pairs of measures on the same animal had the same correlation. All data are presented as least-squares means. When interactions were significant $(P<0.05)$, the Tukey test was used to separate the treatment means.

\section{Results}

Treatments had no effect on feed intake during the digestibility trial or throughout the whole experimental period (Tables 3 and 4). Treatments also did not affect apparent faecal DM, gross energy or aNDFom digestibility, but that of N tended to increase in Gln compared to the Control group $(P=0.078)$. As expected, amino acid supplementation increased the digestible $\mathrm{N}$ content (23.1 vs. $21.4 \mathrm{~g} / \mathrm{kg} \mathrm{DM} ; P=0.015)$ and tended to increase the digestible N/DE ratio compared to Control group $(P=0.077)$. These results led to an increase of digestible $\mathrm{N}$ intake during lactation $(7.8 \mathrm{vs} .7 .1 \mathrm{~g} / \mathrm{d} ; P=0.005)$, although it was not observed among parturitions. Digestible energy intake during lactation was higher in Gln group than in Control and Arg + Gln groups $(P=0.041)$, whereas no effect was found for Gln supplementation once Arg was already included.

Total number kits born per litter tended to increase in rabbit does supplemented with Arg, and Gln compared to Control and Arg + Gln groups (11.5 vs. 10.6; $P=0.095$; Table 5), but no clear effect was observed for the number of kits born alive or dead and, accordingly, on mortality rate at birth $(7.79 \%$ on average; $P=0.18)$. No effect of treatments was observed on the weight of the litter at birth, although the individual weight of the kits tended to be lower in the Gln supplemented group $(P=0.10)$. The initial number kits (once made the adoptions) also tended to be higher for Arg and Gln supplemented groups compared to Control and Arg + Gln groups $(P=0.089)$. This trend was diluted at weaning, where no effect of treatments on the number of weaned rabbits was observed

Table 3

Effect of type of arginine and glutamine supplementation on feed intake and fecal apparent digestibility of nutrients in rabbit does at $21 \mathrm{~d}$ of lactation of the third parturition.

\begin{tabular}{|c|c|c|c|c|c|c|c|c|}
\hline & \multicolumn{4}{|l|}{ Diets } & \multirow[t]{2}{*}{ rsd } & \multicolumn{3}{|l|}{$P$-value } \\
\hline & C & Arg & Gln & $\mathrm{Arg}+\mathrm{Gln}$ & & Arg & Gln & Arg $\times$ Gln \\
\hline Arginine $(\mathrm{g} / \mathrm{kg})$ & 0 & 4 & 0 & 4 & & & & \\
\hline Glutamine $(\mathrm{g} / \mathrm{kg})$ & 0 & 0 & 4 & 4 & & & & \\
\hline Number of rabbit does & 6 & 6 & 6 & 6 & & & & \\
\hline Feed intake ( $\mathrm{g}$ DM/day) & 322 & 340 & 325 & 327 & 41.6 & 0.58 & 0.78 & 0.65 \\
\hline \multicolumn{9}{|l|}{ Faecal apparent digestibility } \\
\hline Dry matter & 0.622 & 0.633 & 0.636 & 0.630 & 0.014 & 0.67 & 0.41 & 0.15 \\
\hline Gross energy & 0.629 & 0.637 & 0.643 & 0.635 & 0.014 & 0.91 & 0.31 & 0.19 \\
\hline Nitrogen & 0.720 & 0.745 & 0.753 & 0.745 & 0.022 & 0.37 & 0.086 & 0.078 \\
\hline Neutral detergent fiber & 0.231 & 0.254 & 0.243 & 0.251 & 0.034 & 0.27 & 0.76 & 0.58 \\
\hline Digestible energy (MJ/kg DM) & 11.6 & 11.8 & 11.8 & 11.7 & 0.26 & 0.82 & 0.45 & 0.12 \\
\hline Digestible nitrogen ( $\mathrm{g} / \mathrm{kg} \mathrm{DM}$ ) & $21.4^{\mathrm{a}}$ & $23.3^{\mathrm{b}}$ & $22.8^{\mathrm{b}}$ & $23.2^{\mathrm{b}}$ & 0.069 & $<0.001$ & 0.036 & 0.015 \\
\hline Ratio digestible [nitrogen/energy] ( $\mathrm{g} / \mathrm{MJ}$ ) & 1.85 & 1.98 & 1.93 & 1.99 & 0.045 & $<0.001$ & 0.038 & 0.077 \\
\hline
\end{tabular}

a,b,c Diet mean values in the same row with a different superscript differ, $P<0.05$. 
Table 4

Effect of arginine and glutamine supplementation and parity order on digestible energy and nitrogen intake of rabbit does.

\begin{tabular}{|c|c|c|c|c|c|c|c|c|c|c|c|c|c|}
\hline & \multicolumn{4}{|l|}{ Diets } & \multicolumn{4}{|c|}{ Parity order } & \multirow[t]{2}{*}{ rsd } & \multicolumn{4}{|c|}{ P-value $^{2}$} \\
\hline & $c$ & Arg & Gln & Arg + Gln & 1 & 2 & 3 & & & Arg & Gln & Arg $\times$ Gln & Parity \\
\hline Arginine $(\mathrm{g} / \mathrm{kg})$ & 0 & 4 & 0 & 4 & & & & & & & & & \\
\hline Glutamine $(\mathrm{g} / \mathrm{kg})$ & 0 & 0 & 4 & 4 & & & & & & & & & \\
\hline Number of rabbit does & 14 & 14 & 15 & 15 & 58 & 58 & & 56 & & & & & \\
\hline \multicolumn{14}{|l|}{ Feed intake of rabbit does $(\mathrm{g} / \mathrm{d})$} \\
\hline Artificial inseminationl-parturition l & 163 & 150 & 155 & 149 & - & - & & - & 22.1 & 0.11 & 0.40 & 0.53 & - \\
\hline Parturition-artificial insemination & 283 & 274 & 287 & 289 & $268^{\mathrm{a}}$ & $285^{\mathrm{ab}}$ & 298 & $98^{\mathrm{b}}$ & 41.7 & 0.68 & 0.25 & 0.51 & 0.003 \\
\hline Lactation $(0-25 d)$ & 332 & 336 & 349 & 333 & $320^{a}$ & $335^{a}$ & 35 & $59^{\mathrm{h}}$ & 38.6 & 0.37 & 0.33 & 0.16 & $<0.001$ \\
\hline Weaning $(25 d) \rightarrow$ next parturition & 185 & 172 & 177 & 180 & 167 & 190 & & - & 33.4 & 0.53 & 0.97 & 0.33 & $<0.001$ \\
\hline Among parturitions & 249 & 251 & 258 & 256 & 240 & 266 & & - & 37.2 & 0.99 & 0.40 & 0.85 & $<0.001$ \\
\hline \multicolumn{14}{|c|}{ Digestible energy intake of rabbit does (MJ/d) } \\
\hline Artificial inseminationl-parturition 1 & 1.89 & 1.77 & 1.83 & 1.74 & - & - & & - & 0.26 & 0.12 & 0.52 & 0.82 & - \\
\hline Parturition-artificial insemination & 3.27 & 3.23 & 3.40 & 3.38 & $3.14^{\mathrm{a}}$ & & $44^{a-b}$ & $3.48^{\mathrm{b}}$ & 0.49 & 0.73 & 0.16 & 0.87 & 0.003 \\
\hline Lactation $(0-25 \mathrm{~d})$ & 3.84 & 3.95 & 4.13 & 3.90 & $3.74^{\mathrm{a}}$ & 3. & & $4.20^{\mathrm{b}}$ & 0.47 & 0.44 & 0.18 & 0.041 & $<0.001$ \\
\hline Weaning ( $25 d) \longrightarrow$ next parturition & 2.13 & 2.02 & 2.10 & 2.10 & 1.95 & 2.2 & & - & 0.39 & 0.55 & 0.82 & 0.52 & $<0.001$ \\
\hline Among parturitions & 2.88 & 2.95 & 3.05 & 2.99 & 2.82 & 3.1 & & - & 0.44 & 0.94 & 0.28 & 0.51 & $<0.001$ \\
\hline \multicolumn{14}{|c|}{ Digestible nitrogen intake of rabbit does $(\mathrm{g} / \mathrm{d})$} \\
\hline Artificial inseminationl-parturition l & 3.49 & 3.49 & 3.53 & 3.45 & - & - & & - & 0.51 & 0.77 & 0.97 & 0.78 & - \\
\hline Parturition-artificial insemination & 6.06 & 6.39 & 6.55 & 6.72 & $6.08^{\mathrm{a}}$ & 6.4 & $6^{\text {ab }}$ & $6.74^{\mathrm{b}}$ & 0.95 & 0.20 & 0.036 & 0.67 & 0.004 \\
\hline Lactation $(0-25 d)$ & $7.11^{\text {a }}$ & $7.83^{\mathrm{b}}$ & $7.97^{\mathrm{b}}$ & $7.74^{\mathrm{b}}$ & $7.25^{\mathrm{a}}$ & 7.6 & & $8.14^{\mathrm{b}}$ & 0.91 & 0.13 & 0.022 & 0.005 & $<0.001$ \\
\hline Weaning (25d) -next parturition & 3.95 & 4.00 & 4.04 & 4.18 & 3.77 & 4.3 & & - & 0.74 & 0.59 & 0.44 & 0.80 & $<0.001$ \\
\hline Among parturitions & 5.33 & 5.84 & 5.87 & 5.94 & 5.45 & 6.0 & & - & 0.84 & 0.11 & 0.084 & 0.23 & $<0.001$ \\
\hline
\end{tabular}

a.b.e Parity order mean values in the same row with a different superscript differ, $P<0.05$.

${ }^{2}$ No significant differences $(P \geq 0.14)$ were found when the interaction $A r g \times G l n \times$ parity was analyzed.

(8.76 on average; $P=0.15$ ) or in the mortality rate during lactation $(11.1 \%$, on average; $P=0.53$ ). In spite of the lack of differences, the weight of the litters at 20 and $25 \mathrm{~d}$ were higher when compared Arg and Gln supplemented groups to Control and Arg + Gln groups (Arg $\times$ Gln interaction: 3.00 vs. $2.85 \mathrm{~kg}$ and 3.77 vs. $3.56 \mathrm{~kg}$, respectively; $P \leq 0.021$ ). No differences were observed in the average weight of kits at 20 or $25 \mathrm{~d}$ of age, average weight gain of kits along lactation or in the kit and litter feed intake between 20

Table 5

Effect of arginine and glutamine supplementation and parity order on performance of rabbit does and their litters.

\begin{tabular}{|c|c|c|c|c|c|c|c|c|c|c|c|c|}
\hline & \multicolumn{4}{|l|}{ Diets } & \multicolumn{3}{|c|}{ Parity order } & \multirow[t]{2}{*}{ rsd } & \multicolumn{4}{|c|}{ p.value ${ }^{2}$} \\
\hline & $\mathrm{c}$ & Arg & Gln & Arg + Gln & 1 & 2 & 3 & & Arg & Gln & Arg $\times$ Gln & Parity \\
\hline Arginine $(\mathrm{g} / \mathrm{kg})$ & 0 & 4 & 0 & 4 & & & & & & & & \\
\hline Glutamine $(\mathrm{g} / \mathrm{kg})$ & 0 & 0 & 4 & 4 & & & & & & & & \\
\hline Number of rabbit does & 14 & 14 & 15 & 15 & 58 & 58 & 56 & & & & & \\
\hline \multicolumn{13}{|l|}{ Number of kits per litter } \\
\hline Total born & 10.3 & 11.6 & 11.3 & 10.9 & $9.88^{\mathrm{a}}$ & $11.2^{\mathrm{a.b}}$ & $12.0^{\mathrm{b}}$ & 3.14 & 0.32 & 0.68 & 0.095 & 0.005 \\
\hline Born alive & 9.58 & 10.5 & 10.5 & 10.2 & 9.30 & 10.5 & 10.8 & 3.19 & 0.55 & 0.55 & 0.22 & 0.055 \\
\hline Born dead & 0.66 & 1.10 & 0.80 & 0.79 & $0.58^{\mathrm{a}}$ & $0.69^{\mathrm{a} . \mathrm{b}}$ & $1.24^{b}$ & 1.20 & 0.30 & 0.68 & 0.27 & 0.028 \\
\hline Initial number (once homogenized) & 9.52 & 10.3 & 10.3 & 9.81 & 9.50 & 10.2 & 10.2 & 2.30 & 0.65 & 0.74 & 0.089 & 0.19 \\
\hline 20 d lactation & 8.40 & 8.95 & 9.07 & 8.80 & 8.59 & 9.17 & 8.66 & 2.01 & 0.65 & 0.40 & 0.20 & 0.30 \\
\hline $25 \mathrm{~d}$ (weaning) & 8.30 & 8.92 & 9.05 & 8.78 & 8.54 & 9.11 & 8.64 & 1.98 & 0.57 & 0.31 & 0.15 & 0.32 \\
\hline Mortality at birth $(\%)$ & 6.11 & 8.85 & 9.60 & 6.59 & 6.31 & 5.98 & 11.1 & 12.9 & 0.95 & 0.77 & 0.18 & 0,13 \\
\hline Mortality during lactation (\%) & 11.3 & 12.2 & 11.2 & 9.73 & $9.49^{\mathrm{a}}$ & $9.65^{\mathrm{a}}$ & $14.2^{\mathrm{b}}$ & 10.2 & 0.89 & 0.49 & 0.53 & 0.040 \\
\hline \multicolumn{13}{|l|}{ Weight of the litter $(\mathrm{kg})$} \\
\hline Weight of litter at birth $(\mathrm{kg})$ & 0.543 & 0.590 & 0.567 & 0.544 & $0.474^{\mathrm{a}}$ & $0.591^{\mathrm{b}}$ & $0.618^{b}$ & 0.14 & 0.63 & 0.64 & 0.13 & $<0.001$ \\
\hline $20 \mathrm{~d}$ & 2.85 & 3.00 & 3.00 & 2.85 & $2.68^{\mathrm{a}}$ & $3.04^{\mathrm{b}}$ & $3.06^{\mathrm{b}}$ & 0.35 & 0.99 & 0.99 & 0.021 & $<0.001$ \\
\hline $25 \mathrm{~d}$ (weaning) & 3.56 & 3.76 & 3.78 & 3.56 & $3.31^{\text {ต }}$ & $3.88^{\mathrm{b}}$ & $3.81^{b}$ & 0.46 & 0.88 & 0.91 & 0.016 & $<0.001$ \\
\hline \multicolumn{13}{|l|}{ Weight of the kits (g) } \\
\hline Birth & 60.5 & 57.2 & 53.6 & 56.2 & 54.6 & 58.0 & 58.0 & 13.4 & 0.88 & 0.10 & 0.22 & 0.32 \\
\hline $20 \mathrm{~d}$ & 353 & 344 & 350 & 340 & 332 & 341 & 367 & 71.8 & 0.46 & 0.76 & 1.00 & 0.082 \\
\hline $25 \mathrm{~d}$ (weaning) & 445 & 430 & 441 & 427 & $411^{a}$ & $436^{2, b}$ & $461^{\mathrm{b}}$ & 89.2 & 0.38 & 0.82 & 1.00 & 0.042 \\
\hline Kits average daily gain $0-25$ (g/d) & 15.0 & 14.5 & 15.1 & 14.5 & $14.1^{\mathrm{a}}$ & $14.8^{\mathrm{a}}$ & $15.4^{\mathrm{b}}$ & 4.62 & 0.37 & 0.97 & 0.98 & 0.22 \\
\hline Kits feed intake $20-25 \mathrm{~d}(\mathrm{~g} / \mathrm{d})$ & 7.16 & 7.86 & 7.55 & 7.35 & $8.60^{\mathrm{b}}$ & $5.94^{\mathrm{n}}$ & $7.90^{\mathrm{b}}$ & 3.26 & 0.67 & 0.92 & 0.46 & $<0.001$ \\
\hline Litter feed intake $20-25 \mathrm{~d}(\mathrm{~g} / \mathrm{d})$ & 59.8 & 63.8 & 68.5 & 64.5 & $75.1^{b}$ & $54.1^{\mathrm{n}}$ & $63.2^{\mathrm{a} . \mathrm{b}}$ & 34.1 & 0.99 & 0.39 & 0.47 & 0.006 \\
\hline $\begin{array}{l}\text { Feed efficiency }(\mathrm{kg}) \text { weaned } / \mathrm{kg} \text { feed doe among } \\
\text { parturition + kits }\end{array}$ & 0.278 & 0.284 & 0.282 & 0.275 & 0.260 & 0.299 & - & 0.06 & 0.98 & 0.87 & 0.65 & $<0.001$ \\
\hline
\end{tabular}

\footnotetext{
$\mathrm{a}_{\mathrm{b}} \mathrm{b}, \mathrm{C}$ Diet mean values in the same row with a different superscript differ. $P<0.05$.

${ }^{2}$ No significant differences ( $P 20.25$ ) were found when the interactions Arg $\times$ parity, Gln $\times$ parity and Arg $\times$ Gln $\times$ parity.
} 
Table 6

Effect of arginine and glutamine supplementation and parity order on doe weight, fertility and milk production of rabbit does.

\begin{tabular}{|c|c|c|c|c|c|c|c|c|c|c|c|c|c|c|c|c|}
\hline & \multicolumn{4}{|l|}{ Diets } & \multicolumn{4}{|c|}{ Parity order } & \multirow[t]{2}{*}{ rsd } & \multicolumn{7}{|l|}{$P$-value ${ }^{2}$} \\
\hline & $\mathrm{C}$ & Arg & Gln & $\mathrm{Arg}+\mathrm{Gln}$ & 1 & 2 & 3 & 4 & & $\operatorname{Cov}^{1}$ & Arg & $G \ln$ & $\operatorname{Arg} \times \operatorname{Gln}$ & Parity & Arg $\times$ Parity & Gln $\times$ Parity \\
\hline Arginine $(g / k g)$ & 0 & 4 & 0 & 4 & & & & & & & & & & & & \\
\hline Glutamine $(g / \mathrm{kg})$ & 0 & 0 & 4 & 4 & & & & & & & & & & & & \\
\hline Number of rabbit does & 14 & 14 & 15 & 15 & 58 & 58 & 56 & 56 & & & & & & & & \\
\hline \multicolumn{17}{|l|}{ Doe weight (g) } \\
\hline Parturition & 4049 & 4014 & 4073 & 4049 & $3988^{\mathrm{a}}$ & $4068^{2 \mathrm{ab}}$ & $4083^{b}$ & - & 313 & - & 0.69 & 0.68 & 0.94 & 0.025 & 0.64 & 0.65 \\
\hline Insemination (11 d) & 4079 & 4096 & 4119 & 4141 & $3953^{\mathrm{a}}$ & $4184^{\mathrm{b}}$ & $4163^{b}$ & $4136^{\mathrm{b}}$ & 326 & _- & 0.80 & 0.58 & 0.98 & $<0.001$ & 0.54 & 0.74 \\
\hline Weaning $(25 d)$ & 4373 & 4363 & 4358 & 4361 & $4294^{a}$ & $4375^{a . b}$ & $4421^{\mathrm{b}}$ & - & 327 & _ & 0.96 & 0.91 & 0.93 & 0.020 & 0.65 & 0.12 \\
\hline Fertility $(\%)$ & 92.3 & 90.5 & 88.1 & 90.5 & $96.5^{b}$ & $83.1^{\mathrm{n}}$ & $91.5^{a . b}$ & - & 20.0 & - & 0.93 & 0.51 & 0.51 & 0.001 & 0.088 & 0.68 \\
\hline \multicolumn{17}{|l|}{ Milk production $(\mathrm{kg})$} \\
\hline $0-10 \mathrm{~d}$ & 1.67 & 1.66 & 1.76 & 1.68 & $1.56^{\mathrm{a}}$ & $1.68^{\mathrm{b}}$ & $1.83^{\mathrm{t}}$ & - & 0.25 & $<0.001$ & 0.34 & 0.29 & 0.45 & $<0.001$ & 0.016 & 0.64 \\
\hline $10-20 \mathrm{~d}$ & 2.44 & 2.47 & 2.63 & 2.49 & $2.33^{\mathrm{a}}$ & $2.53^{\mathrm{b}}$ & $2.65^{\mathrm{b}}$ & - & 0.32 & $<0.001$ & 0.35 & 0.092 & 0.18 & $<0.001$ & 0.18 & 0.37 \\
\hline $20-25 d$ & 1.11 & 1.14 & 1.22 & 1.14 & $1.08^{\mathrm{a}}$ & $1.24^{\mathrm{b}}$ & $1.13^{\mathrm{a}}$ & - & 0.22 & $<0.001$ & 0.64 & 0.24 & 0.26 & $<0.001$ & 0.32 & 0.17 \\
\hline $0-25 \mathrm{~d}$ & 5.22 & 5.28 & 5.62 & 5.31 & $4.99^{\mathrm{a}}$ & $5.45^{\mathrm{b}}$ & $5.63^{b}$ & _- & 0.67 & $<0.001$ & 0.38 & 0.12 & 0.18 & $<0.001$ & 0.085 & 0.38 \\
\hline
\end{tabular}

abs. parity order mean values in the same row with a different superscript differ, $p<0.05$.

${ }^{1}$ Covariates: number of kits at $10 \mathrm{~d}$ for $0-10 \mathrm{~d}$ milk production, number of kits at $20 \mathrm{~d}$ for $10-20 \mathrm{~d}$ milk production. number of kits at $25 \mathrm{~d}$ for $20-25 \mathrm{~d}$ and $0-25 \mathrm{~d}$ milk production.

${ }^{2}$ No significant differences $(P \geq 0.48)$ were found when the interaction $A r g \times G \ln \times$ parity was analyzed. 
Table 7

Effect of arginine and glutamine supplementation over time (parturition, Al and weaning) and parity order on body chemical composition and energy content of rabbit does.

\begin{tabular}{|c|c|c|c|c|c|c|c|c|c|c|c|c|c|c|c|c|c|}
\hline & \multicolumn{4}{|l|}{ Diets } & \multicolumn{4}{|c|}{ Parity order } & \multirow[t]{2}{*}{ rsd } & \multicolumn{8}{|l|}{ p value ${ }^{2}$} \\
\hline & $c$ & Arg & Gln & $\mathrm{Arg}+\mathrm{Gln}$ & 1 & 2 & 3 & 4 & & $\mathrm{Cov}^{1}$ & Arg & Gln & Arg $\times$ Gln & Parity & Arg $\times$ parity & Gln $\times$ parity & $\operatorname{Arg} \times$ Gln $\times$ parity \\
\hline Arginine $(\mathrm{g} / \mathrm{kg})$ & 0 & 4 & 0 & 4 & & & & & & & & & & & & & \\
\hline Glutamine $(\mathrm{g} / \mathrm{kg})$ & 0 & 0 & 4 & 4 & & & & & & & & & & & & & \\
\hline Number of rabbit does & 14 & 14 & 15 & 15 & 58 & 58 & 56 & 56 & & & & & & & & & \\
\hline \multicolumn{18}{|l|}{ Parturition } \\
\hline Moisture $(\mathrm{g} / \mathrm{kg})$ & 610 & 610 & 610 & 617 & 612 & 613 & 609 & -2 & 22.3 & $<0.001$ & 0.40 & 0.44 & 0.45 & 0.47 & 0.20 & 0.52 & 0.59 \\
\hline Protein $(\mathrm{g} / \mathrm{kg})$ & 179 & 179 & 178 & 179 & $179^{b}$ & $179^{\mathrm{b}}$ & $177^{\mathrm{a}}$ & - & 3.23 & $<0.001$ & 0.40 & 0.96 & 0.33 & 0.002 & 0.096 & 0.098 & 0.87 \\
\hline Fat $(g / \mathrm{kg})$ & 146 & 146 & 146 & 138 & 142 & 142 & 147 & - & 23.3 & $<0.001$ & 0.39 & 0.48 & 0.51 & 0.37 & 0.14 & 0.52 & 0.69 \\
\hline $\operatorname{Ash}(g / k g)$ & 31.5 & 31.6 & 31.5 & 31.7 & 31.4 & 31.6 & 31.7 & - & 1.18 & 0.002 & 0.47 & 0.83 & 0.96 & 0.083 & 0.11 & 0.64 & 0.88 \\
\hline Energy $(\mathrm{MJ} / \mathrm{kg}) \mathrm{BW}$ & 11.0 & 10.9 & 11.0 & 10.6 & 10.9 & 10.8 & 11.0 & - & 0.95 & $<0.001$ & 0.40 & 0.45 & 0.44 & 0.45 & 0.21 & 0.54 & 0.60 \\
\hline \multicolumn{18}{|c|}{ Artificial insemination (11 d) } \\
\hline Moisture $(\mathrm{g} / \mathrm{kg})$ & 599 & 598 & 593 & 602 & $594^{a . b}$ & $585^{\text {n }}$ & $604^{\mathrm{b}}$ & $610^{\mathrm{h}}$ & 28.2 & $<0.001$ & 0.50 & 0.87 & 0.40 & $<0.001$ & 0.69 & 0.88 & 0.16 \\
\hline Protein $(g / \mathrm{kg})$ & 181 & 181 & 181 & 182 & $181^{\text {a.b }}$ & $183^{\mathrm{b}}$ & $181^{\mathrm{a}, \mathrm{b}}$ & $180^{\mathrm{n}}$ & 4.16 & 0.062 & 0.85 & 0.90 & 0.49 & 0.019 & 0.23 & 0.73 & 0.85 \\
\hline Fat $(g / k g)$ & 152 & 154 & 158 & 149 & $154^{\mathrm{a}}$ & $165^{\mathrm{b}}$ & $149^{\mathrm{a}}$ & $145^{\text {n }}$ & 26.8 & $<0.001$ & 0.50 & 0.96 & 0.39 & $<0.001$ & 0.65 & 0.92 & 0.15 \\
\hline Ash $(\mathrm{g} / \mathrm{kg})$ & 31.3 & 31.2 & 31.2 & 31.4 & $31.1^{\mathrm{b}}$ & $30.7^{\mathrm{a}}$ & $31.4^{\mathrm{b}-\mathrm{t}}$ & $3.18^{*}$ & 1.11 & $<0.001$ & 0.74 & 0.90 & 0.61 & $<0.001$ & 0.75 & 0.89 & 0.53 \\
\hline Energy $(\mathrm{MJ} / \mathrm{kg}) \mathrm{BW}$ & 11.3 & 11.4 & 11.5 & 11.2 & $11.4^{a . b}$ & $11.8^{b}$ & $11.1^{2}$ & $11.0^{2}$ & 1.11 & $<0.001$ & 0.52 & 0.93 & 0.39 & $<0.001$ & 0.62 & 0.86 & 0.11 \\
\hline \multicolumn{18}{|l|}{ Weaning (25 d) } \\
\hline Moisture $(\mathrm{g} / \mathrm{kg})$ & 629 & 620 & 625 & 632 & $631^{b}$ & $629^{\mathrm{b}}$ & $618^{a}$ & -2 & 28.9 & $<0.001$ & 0.90 & 0.57 & 0.24 & 0.007 & 0.54 & 0.65 & 0.046 \\
\hline Protein $(\mathrm{g} / \mathrm{kg})$ & 179 & 178 & 178 & 179 & $180^{b}$ & $178^{\text {n }}$ & $178^{a}$ & - & 2.69 & $<0,001$ & 0.75 & 0.44 & 0.31 & $<0.001$ & 0.26 & 0.26 & 0.89 \\
\hline Fat $(g / k g)$ & 134 & 142 & 138 & 131 & $130^{\mathrm{a}}$ & $135^{2 . b}$ & $143^{b}$ & - & 26.7 & $<0.001$ & 0.99 & 0.52 & 0.25 & 0.007 & 0.81 & 0.55 & 0.13 \\
\hline Ash $(\mathrm{g} / \mathrm{kg})$ & 30.8 & 30.6 & 30.8 & 30.9 & 30.9 & 30.6 & 30.8 & - & 1.00 & $<0.001$ & 0.96 & 0.51 & 0.55 & 0.25 & 0.55 & 0.13 & 0.97 \\
\hline Energy $(\mathrm{MJ} / \mathrm{kg}) \mathrm{BW}$ & 10.3 & 10.7 & 10.5 & 10.2 & $10.2^{\mathrm{a}}$ & $10.3^{\mathrm{a}}$ & $10.7^{\mathrm{b}}$ & - & 1.17 & $<0.001$ & 0.94 & 0.53 & 0.25 & 0.007 & 0.64 & 0.59 & 0.068 \\
\hline
\end{tabular}

a.b,c Mean values in the same row with a different superscript differ. $P<0.05$

${ }^{1}$ Initial body weight Initial proportion of moisture, protein, fat, ash and energy were not significant as covariates. 
and $25 \mathrm{~d}$ of age. The feed efficiency was not affected by treatments and was on average 0.280 .

Amino acid supplementation did not affect the milk production $(P=0.18$. Table 6$)$, although it was positively correlated with DE and digestible $\mathrm{N}$ intake $(r=0.75 ; P<0.001)$. Only, Arg supplementation groups tended to decrease milk production from the first to the third lactation period compared the other two groups (Arg $\times$ Parity interaction: $P=0.085$. Data not shown), mainly due to a lower milk production the first $10 \mathrm{~d}$ of lactation $(P=0.016)$. A trend for this interaction was also observed for fertility that tended to decrease for Arg supplemented does at the second insemination $(P=0.088)$. Treatments had no effect on the body weight of rabbit does at parturition, insemination or weaning.

There were no significant effects of treatments on body weight, chemical composition and energy content of rabbit does (Table 7). However, rabbit does supplemented with Arg or Gln tended to have a higher body energy content at the third insemination and weaning than those from Control and $\operatorname{Arg}+\operatorname{Gln}$ groups (Arg $\times \operatorname{Gln} \times$ Parity interaction: $P \leq 0.11$. Data not shown).

Amino acid supplementation did not modify the replacement rate of rabbit does that was high ( $32.9 \%$ on average. Data not shown), most of it due to the mortality just before parturition ( $31.6 \%$ on average).

Multiparous rabbit does had a higher feed, digestible $\mathrm{N}$ and energy intake, total number of kits born per litter, weight of the litter at birth and at weaning, milk production and feed efficiency than primiparous does (Tables 4-6. $P \leq 0.005$ ), although they showed a similar number of kits at weaning. Fertility rate was lower in the second insemination compared to the first one $(P=0.001)$. The body weight at parturition and at weaning of multiparous does were higher and body protein proportion lower respect to primiparous does $(P \leq 0.025)$, whereas the variations of fat proportion depended on the physiological state, with no effect at parturition (Table 7). The temporal evolution with the productive/reproductive events (five reproductive cycles) of body composition, energy content and weight of all the rabbit does considered in this study is showed in Fig. 1A (time effect: $P<0.001$ for all traits). In Fig. $1 \mathrm{~B}$ is represented this evolution but only for rabbit does that had five consecutive and successful inseminations ( $n=14)$. These highly productive rabbit does had a similar initial protein content, with a reduced variation along time, but a lower body weight and fat proportion compared to the average obtained considering all the rabbit does $(P<0.001)$. Highly productive primiparous does tended to mobilize a higher fat proportion from the second insemination until the first weaning compared to the standard does (11.0 vs. $22.8 \% ; P=0.051)$.

\section{Discussion}

The single supplementation with Arg or Gln tended to increase the number of kits born per litter and the litter size once made the adoptions. These results are partially in agreement with the positive effect of Arg supplementation on prolificacy obtained in sows ( $1 \%$ Arg; + 2 piglets; Mateo et al., 2007; 0.8\% Arg; + 3.7 piglets; Berard and Bee, 2010) and rats (1.3\% Arg; + 3 rats; Zeng et al., 2008). In rats Arg supplementation increased the number of implantation sites and the litter size at birth, but in pigs these authors did not found any effect on the total number of piglets born per litter, but a great effect on the piglet survival rate at birth, effect that was not observed in this study. Accordingly, the minor magnitude of the effect of Arg supplementation found in this study might be due to the lower dose of Arg employed. Arginine is a common substrate for nitric oxide and polyamine syntheses, and nitric oxide plays an important role in regulating placental-fetal blood flows (Bird et al., 2003), contributing to maternal systemic vasodilatation during pregnancy and regulating the uterine and fetal placental blood flow (Sladek et al., 1997). In this way, recent results obtained in rabbits revealed that the probability of mortality of fetuses is three times higher if they receive a single vein than if they receive two or more veins (Damico et al., 2013). Furthermore, nitric oxide might influence positively the final litter size as it also induced the follicle rupture in vitro in the rabbit ovaries (Yamauchi et al., 1997).

The positive trend observed of Gln supplementation on the initial litter size might be accounted for the benefit of Gln on the in vitro development of oocytes (in hamsters and rabbits; Gwatkin and Haidri, 1973; Bae and Foote, 1975) and embryos (in hamsters and pigs; Carney and Bavister, 1987Petters et al., 1990), which might be linked to the use of Gln as an energy source. In this sense, Gln was among the most abundant amino acids in the pig follicular fluid and its supplementation in a maturation medium improved fertilization and preimplantation development (Hong and Lee, 2007). Furthermore, Gln (but also Arg) is very abundant in fetal fluids in the first part of pregnancy of sows, when the growth of placenta is more rapid (Wu and Knabe, 1994; Newsholme and Calder, 1997; Self et al., 2004), and it is associated with a high placental nitric oxide and polyamine synthesis and accordingly with fetal development (Wu et al., 2007). However, no positive effect of $1 \% \mathrm{Gln}$ in gestating sows was reported on litter size at birth (Wu et al., 2011). Glutamine supplementation in sows, and not Arg, increased the average birth weight of piglets (Mateo et al., 2007; Wu et al., 2011) that contrasts with the trend found in this study in rabbits to reduce it.

Nevertheless, the trend observed on the initial litter size was diluted along the lactation period due to mortality, and no effect of single Arg or Gln supplementation on the litter size at weaning was found. However, the litter size at weaning might be responsible for the higher litter weight at weaning when supplemented only with Arg or Gln, because both variables were positively correlated $(r=0.65 ; P<0.001$ ), and no effect on milk production (only Arg supplemented does tended to reduce milk production at the third lactation) or in the average growth rate of kits during lactation were found. This situation differs from that reported when sows were supplemented with $1 \%$ of Arg or Gln, where the average growth rate of piglets during lactation increased, and Gln supplementation also decreased preweaning mortality (Mateo et al., 2008; Wu et al., 2011).

In spite of the heavier litters obtained at weaning when supplemented with Arg or Gln no impairment on body condition was found in rabbit does, and even does of these groups tended to have a greater energy content at the end of the third lactation compared to Control and Arg + Gln groups. It might be related with an improved nitrogen metabolism as Arg supplementation reduced serum/ plasmatic urea concentrations in pigs and rats (Mateo et al., 2007; Zeng et al., 2008) or with a spare of branched amino acids when Gln is supplemented, although in this case no influence on plasmatic urea concentrations were observed (Wu et al., 2011). 
There was no additive effect of the simultaneous supplementation of Arg and Gln and, in some traits (litter size at birth, litter weight at weaning, or doe energy content at the third lactation), Arg + Gln group tended to show closer values to Control group. There is no previous information about this lack of synergism between Arg and Gln on reproductive traits, although the single supplementation of these amino acids seem to exert different effects on the blood concentration of the other one. The single supplementation of Arg decreased the plasmatic Gln concentration in pregnant gilts (Mateo et al., 2007; Berard and Bee, 2010), whereas the single Gln supplementation increased the plasmatic Arg concentration (Wu et al., 2011). In pregnant rats, the single supplementation of Arg, exerted the opposite effect, and increased the serum Gln concentration (Zeng et al., 2008). In a very different scenario, when the gut barrier function traits are studied the combined supplementation of both amino acids did not improve the single supplementation of Gln in rabbits (Chamorro et al., 2010) or the single supplementation of Arg or Gln in rats (Beutheu et al., 2014).

These results suggest that the physiological period to supplement these amino acids might be different if a synergistic effect is wanted and with a higher dose than the one used in this study. The different way of action of Arg and Gln to promote prolificacy might recommend to supplement Gln few days before insemination until at least embryo implantation (7-8 d after insemination), where fertilization and implantation occurs (Harper, 1961; Denker, 1977), whereas Arg supplementation could be made few days before implantation until the end of pregnancy.

The effects observed for the parity order were those expected and similar to those previously described (Pascual et al., 1999; Xiccato et al., 2004; Rebollar et al., 2009). Highly productive does tended to have less fat content at the beginning of the experiment, and showed a numerically lower fat mobilization before the first parturition (but not significant) and a similar fat restoration from birth to next insemination than the average obtained considering all the rabbit does, which agrees with the results reported by Savietto et al. (2016). However, it contrasts with the continuous mobilization of fat reserves along the first lactation reported by Fortun-Lamothe (2006). From the second insemination until the first weaning, highly productive does were able to mobilize in a greater extent their fat reserves compared the average population, and this trend was also observed in successive parturitions. These results question whether the ability of highly productive does in the use of fat reserves accounts for the reproductive success or, on the opposite, the latter is influencing their body condition.

\section{Conclusions}

The single supplementation of Arg and Gln had a positive effect on the weight of litters at weaning and litter size at birth. No additive effect was observed for the combined supplementation of Arg and Gln. Further research is required to establish the optimal dose and the best period for their supplementation.

\section{Acknowledgments}

This research was supported by the Ministerio de Economía y Competitividad (project AGL2011-23885 and grant obtained by Rebeca Delgado, BES-2012-055392). We greatly appreciate the collaboration of Ajinomoto Eurolisyne SAS (Paris, France) and Indukern SA (Barcelona, Spain) for providing Arginine and Glutamine, and Dr. Enrique Blas and his team (Universidad Politécnica de Valencia, Spain) for the manufacturing of experimental diets.

\section{References}

Argente, M.J., Santacreu, M.A., Climent, A., Blasco, A., 2003. Relationships between uterine and fetal traits in rabbits selected on uterine capacity. J. Anim. Sci. 81 . 1265-1273.

Association of Official Analytical Chemists, 2000. Official Methods of Analysis, 17th ed. AOAC, Washington, DC:

Bae, I., Foote, R.H., 1975. Carbohydrate and amino acid requirements and ammonia production of rabbit follicular oocytes matured in vitro. Exp. Cell Res. 91 , $113-118$.

Baylos, M., Menovo, D., Chamorro, S., Sainz, A., Nicodemus, N., de Blas, C., Carabaño, R., 2008. Effect of dietary level and source of glutamine on intestinal health in the postweaning period. In: Proc.: 9th World Rabbit Congress. 10-13 June, 2008, Verona, Italy. .

Blasco, A., Bidanel, J.P., Bolet, G., Haley, C.S., Santacreu, M.A., 1993. The genetic of prenatal survival of pigs and rabbits: a review. Livest. Prod. Sci. 37, 1-21.

Berard, J., Bee, G., 2010. Effect of dietary L-arginine supplementation to gilits during early gestation on foetal survival, growht and myofiber formation. Animal 4 . 1680-1687.

Beutheu, S., Ouelaa, W., Guérín, C., Belmonte, L.. Aziz, M., Tennoune, N., Bôle-Feysot, C., Galas, L., Déchelotte, P., Coëffier, M., 2014. Glutamine supplementation, but not combined glutamine and arginine supplementation, improves gut barrier function during chemotherapy-induced intestinal mucositis in rats. Clin. Nutr. 33 , $694-701$.

Bird, I.M., Zhang, L., Magness, R.R., 2003. Possible mechanisms underlying pregnancy-induced changes in uterine artery endothelial function. Am. J. Physiol. Regul. Integr. Comp. Physiol, 284, R245-R258.

BOE, 2005. Boletín Oficial del Fstado, Real Decreto 1201/2005. Sobre protección de los animales utilizados para experimentación y otros fines cientificos. Boletín Oficial del Estado, España. 252, 34367-34391.

Carney, E.W., Bavister, B.D., 1987. Stimulatory and inhibitory effects of amino acids on the development of hamster eight-cell embryos in vitro. J. In Vitro Fertil. Embryo Transfer 4, 162-167.

Gartuche, L., Pascual, M., Gómez, E.A., Blaseo, A., 2014. Economic weights in rabbit meat production. World Rabbit Sci. 22, 165-177.

Chamorro, S., de Blas, C., Grant, G., Badiola, I., Menoyo, D., Carabano, R., 2010. Effect of dietary supplementation with glutamine and a combination of glutaminearginine on intestinal health in twenty-five-day-old weaned rabbits. J. Anim. Sci. 88, 170-180.

Damico, J., Torres, C., Argente, M.J., García, M.L, 2013. Study of uterine and foetal traits of the rabbit female at 12 days of gestation. World Rabbit Sci. 21, $209-210$. De Blas, C., Mateos, G.G., 2010. Feed formulation. In: De Blas, C., Wiseman, J. (Eds.), Nutrition of the Rabbit, second ed. pp. $222-232$.

Denker, H.W., 1977. Implantation. The role of proteinases, and blockage of implantation by proteinase inhibitors. Adv. Anat. Embryol. Cell Biol. 53, 3-123.

Duncan, S.L.B., 1969. The partition of uterine blood flow in pregnant rabbit. J. Physiol, 204, 421-433.

Fortun-Lamothe, L., 2006. Energy balance and reproductive performance in rabbit does, Anim. Reprod. Sci. 93, 1-15. 
Gwatkin, R.B.L., Haidri, A.A., 1973, Requirements for the maturation of hamster oocytes in vitro. Exp. Cell. Res. $73,1-7$.

Harper, M.J., 1961. The time of ovulation in the rabbit following the injection of luteinizing hormone. J. Fndocrinol. 22, 147-152.

Hong, J., Lee, E., 2007. Intrafollicular amino acid concentration and the effect of amino acids in a defined maturation medium on porcine oocyte maturation, fertilization, and preimplantation development. Theriogenology 68, 728-735.

INRA, 1984. In: Blum, J.C. (Ed.), L’alimentation des animaux monogastriques: Porc, Lapin, Volailles. Institute de la Recherche Agronomique, Paris, France.

Li, P., Kim, S.W., Li, X.L., Datta, S., Pond, W.G., Wu, G., 2009. Dietary supplementation with cholesterol and docosahexaenoic acid affect concentrations of amino acids in tissues of young pigs. Amino Acids 37, 709-716.

Littell, R.C., Milliken, G.A., Stroup, W.W., Woifinger, R.D., 1996. SAS System for Mixed Models. SAS Institute Inc, Cary, NC.

Littell, R.C., Henry, P.R., Ammerman, C.B., 1998. Statistical analysis of repeated measures data using SAS procedures. J. Anim. Sci. 76, 1216-1231.

Mateo, R.D., Wu, G., Bazer, W.B., Park, J.C., Shinzato, I., Kim, S.W., 2007. Dietary L-arginine supplementation enhances the reproductive performance of gilts. J. Nutr. $137,652-656$.

Mateo, R.D., Wu, G., Moon, H.K., Carroll, J.A., Kim, W., 2008. Effects of dietary arginine supplementation during gestation and lactation on the performance of lactating primiparous sows and nursing piglets. J. Anim. Sci. 86, 827-835 677.

Mertens, D.R., Allen, M., Carmany, J., Clegg, J., Davidowicz, A., Drouches, M., Frank, K, Gambin, D., Garkie, M, Gildemeister, B., Jeffress, D., Jeon, C.S., Jones, D., Kaplan, D., Kim, G.N., Kobata, S., Main, D., Moua, X., Paul, B., Robertson, J., Taysom, D., Thiex, N., Williams, J., Wolf, M., 2002, Gravimetric determination of amylase-treated neutral detergent fiber in feeds with refluxing I beakers or crucibles: collaborative study. J. AOAC. Int. 85, 1217-1240.

Moncada, S., Higgs, E., 1995. Molecular mechanisms and therapeutic strategies related to nitric oxide. FASEB J. 9, 1319-1330.

Nicodemus, N., Pereda, N., Romero, C., Rebollar, P.G., 2009. Évaluatuion de la technique dimpédance bioélectrique (IBE) puor estimer la composition corporelle de lapines reproductrices. En Proc: 13émes Jornées de la Recherche Cunicole 109-112.

Newsholme, E.A., Calder, P.C., 1997. The proposed role of glutamine in some cells of the immune system and speculative consequences for the whole animal, Nutrition 13. $728-730$

NRC, 2012. Nutrient Requirements of Swine, 11th ed. National Academy Press, Washington, DC.

Pascual, J., Tolosa, G., Cervera, C., Blas, E., Fernández-Carmona, J., 1999. Effect of diets with different digestible energy content on the performance of rabbit does. Anim. Feed Sci. Technol. 81, 105-117.

Pereda, N., 2010. Evaluación de la técnica del Análisis de Impedancia Bioeléctrica (BIA) para predecir la composición corporal; aplicación en conejas sometidas a diferentes sistemas de alimentación durante la recría. Ph D Thesis. UPM. Madrid, Spain.

Petters, R.M., Johnson, B.H., Reed, M.L. Archibong, A.E., 1990. Glucose, glutamine and inorganic phosphate in early development of the pig embryo in vitro. J. Reprod. Fert. $89,269-275$.

Quintela, L.A., Peña, A.I., Vega, M.D., Gullón, J., Prieto, M.C., Barrio, M., Becerra, J.J., Maseda, F., Herradón, P.G., 2004. Ovulationinduction in rabbit does submitted to artificial insemination by adding buserelin to the seminal dose. Reprod. Nutr. Dev. 44, 79-88.

Rebollar, P.G., Milanés, A., Pereda, N., Millán, P., Cano, P., Esquifino, A.I., Villarroel, M., Silván, G., Lorenzo, P.L., 2006. Oestrussynchronisation of rabbit does at early post-partum by doe-litter separation or ECG injection: reproductive parameters and endocrine profiles. Anim. Reprod. Sci. 93, $218-230$.

Rebollar, P., Pérez-Cabal, M., Pereda, N., Lorenzo, P., Arias-Álvarez, M., García-Rebollar, P., 2009. Effects of parity order and reproductive management on the efficiency of rabbit productive systems. Livest. Sci. 121, 227-233.

Romero, C., Nicodemus, N., Martínez de Morentin, C., García, A., de Blas, C., 2011. Effect of grinding size of barley and dehydrated alfalfa on performance and body composition of does during their early reproductive cycles. Livest. Sci. 140, 55-61.

Savietto, D.. Marono, S., Martínez, I. Martínez-Paredes, E., Rodenas, L., Cervera, C., Pascual, J.J., 2016. Patterns of body condition use and its impact on fertility. World Rabbit Sci. 24, 39-45.

Self, J.T., Spencer, T.E., Johnson, G.A., Hu, J.B., Bazer, F.W., Wu, G.Y., 2004. Glutamine synthesis in the developing porcine placental. Biol. Reprod. 70. 1444-1451.

Sladek, S.M., Magness, R.R., Conrad, K.P., 1997. Nitric oxide and pregnancy. Am. J. Physiol. Regul. Integr. Comp. Physiol. 272 (2), R441-R463.

Van Soest, P.J., Robertson, J.B., Lewis, B.A., 1991. Methods for dietary fiber, neutral detergent fiber, and nonstarch polysaccharides in relation to animal nutrition. J. Dairy Sci. 74, 3583-3597.

Wu, G., Knabe, D.A., 1994. Free and protein-bound amino acids in sow's colostrum and milk. J. Nutr. 124, 415-424.

Wu, G.Y., Morris, S.M., 1998. Arginine metabolism: nitric oxide and beyond. Biochem. J. 336, 1-17.

Wu, G., Pond, W.G., Ott, T., Bazer, F.W., 1998. Maternal dietary protein deficiency decreases amino acid concentrations in fetal plasma and allantoic fluid of pigs. J. Nutr. 128, 894-902.

Wu, G., Ott, T.L., Knabe, D.A., Bazer, F.W., 1999. Amino acid composition of the fetal pig. J. Nutr. 129, $1031-1038$.

Wu, G., Bazer, F.W., Cudd, T.A., Meininger, C.J., Spencer, T.E.. 2004. Maternal nutrition and fetal development. J. Nutr. 134, $2169-2172$.

Wu, G., Bazer, F.W., Hu, J., Johnson, G.A., Spencer, T.E., 2005. Polyamine synthesis from proline in the developing porcine placenta. Biol. Reprod. 72, $842-850$.

Wu, G., Bazer, F.W., Davis, T.A., Jaeger, L.A., Johnson, G.A., Kim, S.W., Knabe, D.A., Meininger, C.J., Spencer, T.E., Yin, Y., 2007. Important roles for the arginine family amino acids in swine nutrition and production. Livest. Sci. 112, 8-22.

Wu, G.Y., 2009. Amino acids: metabolism, functions, and nutrition. Amino Acids 37, 1-17.

Wu, G.F., Bazer, F.W., Johnson, G.A., Knabe, D.A., Burghardt, R.C., Spencer, T.E., Li, X.L.. Wang, J.J., 2011. Important roles for L-glutamine in swine nutrition and production. J. Anim. Sci. 89, 2017-2030.

Xiccato, G., Trocino, A., Sartori, A., Queaque, P.1., 2004. Effect of parity order and litter weaning age on the performance and body energy balance of rabbit does. Livest. Prod. Sci. 85, 239-251.

Xiccato, G., Trocino, A., 2010. Energy and protein metabolism. In: De Blas, C., Wiseman, J. (Eds.), Nutrition of the Rabbit, second ed. pp. 83-118.

Yamauchi, J., Miyazaki, T., Iwasaki, S., Kishi, I., Kuroshima, M., Tei, C., Yoshimura, Y., 1997. Effects of nitric oxide on ovulation and ovarian steroidogenesis and prostaglandin production in the rabbit. Endocrinology 138, 3630-3637.

Zeng, X., Wang, F., Fan, X., Yang, W., Zhou, B., Li, P., Yin, Y.. Wu, G., Wang, J., 2008. Dietary arginine supplementation during early pregnancy enhances embryonic survival in rats. J. Nutr. 138, 1421-1425. 